\title{
PENGARUH PENGGUNAAN MULTIMEDIA ANIMASI TERHADAP PENINGKATAN PENGUASAAN KONSEP MATERI PENGUATAN LOGAM PADA MATA KULIAH MATERIAL TEKNIK
}

\author{
Darul Quthni ${ }^{1}$, Ariyano ${ }^{2}$, Yayat $^{3}$ \\ Departemen Pendidikan Teknik Mesin \\ Universitas Pendidikan Indonesia \\ Jl. Dr. Setiabudhi No. 207 Bandung 40154 \\ daru12712@gmail.com
}

\begin{abstract}
ABSTRAK
Penelitian ini bertujuan untuk mengetahui pengaruh penggunaan multimedia animasi terhadap peningkatan Penguasaan Konsep mahasiswa DPTM UPI pada pembelajaran materi Penguatan Logam dengan mengimplementasikan multimedia animasi dibandingkan dengan menggunakan media diktat. Metode penelitian yang digunakan adalah metode penelitian kuasi eksperimen, dengan menggunakan pola desain Nonequivalent Control Group Design. Pengumpulan data dilakukan menggunakan tes pilihan ganda yang berbeda, tes dilakukan sebelum dan sesudah mahasiswa diberikan treatment. Hasil penelitian yang dilihat dari nilai rata-rata $N$-Gain dari masing-masing kelompok menunjukkan pengaruh penggunaan multimedia animasi terhadap peningkatan penguasaan konsep. Kelas yang menggunakan multimedia animasi berada pada kategori sedang, sedangkan kelas yang menggunakan media diktat yang berada pada kategori rendah. Kesimpulan diperoleh bahwa terdapat pengaruh penggunaan multimedia animasi terhadap peningkatan penguasaan konsep pada pembelajaran materi Penguatan Logam.
\end{abstract}

Kata kunci: multimedia animasi, penguasaan konsep, penguatan logam

\section{PENDAHULUAN}

Mata kuliah Material Teknik dalam kurikulum Departemen Pendidikan Teknik Mesin (DPTM), Fakultas Pendidikan Teknologi dan Kejuruan (FPTK), Universitas Pendidikan Indonesia (UPI) merupakan mata kuliah dasar pada semester satu dengan jumlah kredit dua SKS yang termasuk pada kelompok mata kuliah keahlian program studi. Mata kuliah ini diberikan pada tiga konsentrasi, yaitu; otomotif, produksi dan perancangan, dan refrigasi dan tata udara. Mata kuliah material teknik merupakan mata kuliah prasyarat untuk menempuh mata kuliah lanjutan yang berhubungan dengan sifat mekanik dan sifat logam.

Secara umum material teknik diperlukan terutama berhubungan dengan sifat-sifat mekanik, dan sifat-sifat teknologi dari material khususnya logam. Semua sifat material tersebut ditentukan oleh struktur atom-atomnya secara mikro. Sifat material khususnya logam dibangun atas dua konsep utama yaitu konsep struktur kristal atom dan konsep perlakuan

\footnotetext{
${ }^{1}$ Mahasiswa Departemen Pendidikan Teknik Mesin FPTK UPI

${ }^{2}$ Dosen Departemen Pendidikan Teknik Mesin FPTK UPI

${ }^{3}$ Dosen Departemen Pendidikan Teknik Mesin FPTK UPI
} 
logam. Konsep struktur kristal atom menjelaskan bagaimana atom-atom tersusun pada setiap jenis logam, dan pada kondisi yang berbeda-beda bisa menyebabkan perbedaan sifat. Sementara konsep perlakuan logam menjelaskan interaksi antar atom dan perubahan struktur atom yang mengakibatkan perubahan sifat-sifat pada logam. Secara umum konsep-konsep tersebut menggambarkan kejadian yang abstrak karena kecilnya ukuran atom-atom yang tidak bisa dilihat dengan mata telanjang.

Mata kuliah ini memiliki beberapa pokok bahasan, dan salah satunya adalah penguatan logam. Pokok bahasan penguatan logam memiliki beberapa sub pokok bahasan yang harus disampaikan kepada mahasiswa yaitu dislokasi, penghalusan butir, perlakuan panas dan pemaduan. Pada proses perkuliahan penjelasan konsep-konsep pokok bahasan tersebut hanya dijelaskan menggunakan gambar dan teks melalui diktat, sedangkan permasalahan dalam pembelajaran material teknik yaitu mahasiswa kesulitan memahami konsep yang abstrak dan kompleks, sehingga materi penguatan logam termasuk pokok bahasan yang sulit dipahami mahasiswa. Hal ini terlihat dari masih adanya mahasiswa (20\% mahasiswa) yang mengalami kesulitan dalam menguasai pokok bahasan tersebut. Hal ini disebabkan rendahnya kemampuan mahasiswa dalam penguasaan konsep pada materi penguatan logam. Sisanya mahasiswa mengalami kesulitan pada pokok bahasan lainnya.

Kesulitan-kesulitan pada pokok bahasan penguatan logam dinilai cukup tinggi dan dapat menjadi kendala yang besar pada proses pembelajaran. Kesulitan pada materi penguatan logam diduga disebabkan oleh beberapa hal, yaitu: (1) Karakteristik pokok bahasan penguatan logam yang abstrak dan kompleks, (2) Kurangnya referensi yang dimiliki, (3) Kurangnnya media pembelajaran yang dapat mengatasi kendala yang ada sehingga mahasiswa kesulitan untuk memahaminya.

Pokok bahasan penguataan logam ini menitik beratkan pada jenis konsep relasional yang merupakan bagian dari jenis konsep struktur. Dimana pada konsep jenis ini mahasiswa harus dapat menyatakan hubungan yang terjadi pada setiap atribut konsep yang ada. Konsep tersebut harus dikuasai dengan baik, sehingga mahasiswa dapat memahami pokok bahasan yang diajarkan. Penguasaan konsep merupakan kemampuan mahasiswa dalam memahami konsep-konsep setelah kegiatan pembelajaran. Penguasaan konsep dapat diartikan sebagai kemampuan mahasiswa dalam memahami makna secara ilmiah, baik konsep secara teori maupun penerapannya dalam kehidupan sehari-hari (Dahar, 2011). 
Penguasaan konsep diperoleh dari proses belajar, sedangkan belajar merupakan proses kognitif yang melibatkan tiga proses yang hampir bersamaan yaitu memperoleh informasi yang baru, transformasi informasi, dan menguji relevansi ketetapan pengetahuan. Seseorang dikatakan menguasai konsep apabila orang tersebut mengerti benar konsep yang dipelajarinya, sehingga mampu menjelaskan dengan menggunakan kata-kata sendiri sesuai dengan pengetahuan yang dimilikinya. Penguasaan konsep dapat diartikan sebagai kemampuan seseorang dalam mengungkapkan kembali suatu objek tertentu berdasarkan ciri-ciri yang dimiliki oleh objek tersebut.

Mengingat pentingnya mata kuliah material teknik, dan berdasarkan data yang menunjukan bahwa mahasiswa mengalami kesulitan pada materi penguatan logam, maka diperlukan suatu upaya perbaikan agar proses mudah dipahami. Salah satu usaha yang dapat dilakukan adalah dengan media pembelajaran yang tidak hanya dalam tataran teoritis, tetapi sebuah media praktis, ekonomis, mudah dijangkau (acceessible), dan mudah diajarkan (teachable), sehingga memungkinkan suatu bahan dapat dipelajari secara berulang. Upaya untuk memenuhi kriteria media praktis, ekonomis, acceessible, dan teachable akan ditempuh dengan manipulasi model teoritis (gambar) menjadi model realistis dalam bentuk multimedia animasi. Karena multimedia animasi memiliki ciri manipulatif yakni mampu mengubah model teoritis menjadi model realistis (animasi), sehingga dapat menarik perhatian dalam proses pembelajaran dan memudahkan untuk memahami materi pembelajaran.

\section{METODE PENELITIAN}

Metode penelitian yang digunakan dalam penelitian ini adalah Quasi Experimental Design dalam bentuk Nonequivalent Control Group Design. Pemilihan desain penelitian ini adalah sulitnya mendapatkan kelompok kontrol yang dapat berfungsi sepenuhnya untuk mengontrol variabel-variabel luar yang mempengaruhi pelaksanaan eksperimen. Desain ini (Nonequivalent Control Group Design) hampir sama dengan pretest-posttest control group design, hanya pada desain ini kelompok eksperimen maupun kelompok kontrol tidak dipilih secara random.

Terdapat dua kelompok yang terdiri dari kelompok eksperimen dan kelompok kontrol yang tidak dipilih secara random. Kedua kelompok tersebut diberi pretest untuk mengetahui perbedaan kemampuan awal antara kelompok eksperimen dan kelompok kontrol. Setelah 
diberikan pretest, kedua kelompok tersebut diberi treatment yang berbeda yaitu pembelajaran dengan menggunakan multimedia animasi pada kelompok eksperimen dan pembelajaran menggunakan media diktat pada kelas kontrol. Selanjutnya diberi posttest untuk mengetahui perbedaan hasil belajar antara kedua kelompok. Soal pretest dan posttest yang digunakan dibuat sama namun untuk soal posttest dimodifikasi dengan cara mengacak nomor soal pretest, hal tersebut dilakukan sama untuk kelompok kelas eksperimen maupun kelompok kontrol.

\section{HASIL PENELITIAN}

Hasil penelitian menunjukkan bahwa varian kedua kelompok homogen, pengujian pada penelitian ini dapat dilanjutkan menggunakan analisis data Statistik Parametrik metode uji t dan jumlah anggota sampel $n_{1}=n_{2}$ dan varian homogen $\left(\sigma_{1}{ }^{2}=\sigma_{2}{ }^{2}\right)$ maka dapat digunakan rumus t-test 3.16 maupun 3.17. Untuk melihat harga t-tabel digunakan $\mathrm{dk}=\mathrm{n}_{1}+\mathrm{n}_{2}-2$. Hasil pengolahan data untuk menjawab rumusan hipotesis, yaitu uji $\mathrm{N}$-Gain, dan uji t. Pengolahan data dapat dibagi menjadi dua analisis, yaitu uji $N$-Gain dan uji t.

Data hasil pretest dan posttest kelompok kontrol dan kelompok eksperimen yang diolah menghasilkan nilai rata-rata Gain 5,33 untuk kelompok kontrol dan nilai rata-rata Gain 9,73 untuk kelompok eksperimen. Rata-rata Gain dari masing-masing kelompok selanjutnya diolah menjadi $N$-Gain, yang menghasilkan rata-rata $N$-Gain 0,283 untuk kelompok kontrol, dan nilai rata-rata $N$-Gain 0,526 untuk kelompok eksperimen.

Hasil perhitungan $\mathrm{N}$-Gain, jika rata-rata $\mathrm{N}$-Gain kedua kelompok dibandingkan, maka rata-rata $\mathrm{N}$-Gain kelompok eksperimen termasuk kriteria sedang karena lebih besar dibandingkan rata-rata $N$-Gain kelompok kontrol yang termasuk kriteria rendah. Berdasarkan hasil perhitungan $\mathrm{N}$-Gain, maka dapat dikatakan bahwa peningkatan penguasaan konsep kelompok eksperimen lebih baik daripada peningkatan penguasaan konsep kelompok kontrol. Uji t yang dilakukan terhadap data $N$-Gain kelompok kontrol dan kelompok eksperimen dengan taraf signifikansi $\alpha=0,05, \mathrm{dk}=28$, dan pengujian pihak kanan menghasilkan nilai $\mathrm{t}_{\text {hitung }}$ adalah 4,266, dan nilai $\mathrm{t}_{(0,95 ; 28)}$ adalah 2,048.

$\mathrm{H}_{\mathrm{o}}$ ditolak dan $\mathrm{H}_{\mathrm{a}}$ diterima, artinya $N$-Gain kelompok eksperimen lebih baik daripada $N$-Gain kelompok kontrol. Pengambilan keputusan bahwa $\mathrm{H}_{\mathrm{o}}$ ditolak dan $\mathrm{H}_{\mathrm{a}}$ diterima, didukung oleh hasil perhitungan nilai $p$-value. Berdasarkan nilai $p$-value $(0,0002)<\alpha(0,05)$, 
maka peneliti berani menolak $\mathrm{H}_{\mathrm{o}}$ dan menerima $\mathrm{H}_{\mathrm{a}}$, karena resiko sebesar $0,02 \%$ lebih kecil daripada taraf signifikansi yang telah ditetapkan yaitu 5\%. Berdasarkan hasil dari uji t, maka dapat dikatakan bahwa penggunaan multimedia animasi berpengaruh terhadap penguasaan konsep mahasiswa pada pembelajaran materi Penguatan Logam.

\section{PEMBAHASAN}

Hasil pengolahan data pretest dan posttest yang telah dilakukan menunjukkan bahwa adanya pengaruh terhadap penguasaan konsep mahasiswa yang diberikan pembelajaran dengan menggunakan multimedia animasi. Ini ditunjukkan dengan hasil post-test dan nilai rata-rata $\mathrm{N}$-Gain kelas eksperimen yang lebih besar nilainya dibandingkan dengan kelas kontrol. Diketahui bahwa kelas eksperimen diberikan pembelajaran menggunakan multimedia animasi sedangkan kelas kontrol diberikan pembelajaran dengan menggunakan diktat. Pada proses pembelajarannya dari masing-masing kelompok, menunjukkan bahwa terdapat peningkatan hasil belajar yang dapat dilihat dari lebih besarnya rata-rata hasil posttest daripada rata-rata hasil pretest dari masing-masing kelompok.

Perbedaan peningkatan hasil belajar dari kedua kelompok juga sejalan dengan hasil perhitungan menggunakan uji t, yang menghasilkan keputusan $\mathrm{H}_{\mathrm{o}}$ ditolak dan $\mathrm{H}_{\mathrm{a}}$ diterima, yang artinya $N$-Gain kelompok eksperimen lebih baik daripada $N$-Gain kelompok kontrol. Pengambilan keputusan bahwa $\mathrm{H}_{\mathrm{o}}$ ditolak dan $\mathrm{H}_{\mathrm{a}}$ diterima, didukung oleh hasil perhitungan nilai $p$-value pada uji t. Berdasarkan nilai p-value yang lebih kecil dari nilai $\alpha$, sehingga peneliti berani menolak $\mathrm{H}_{\mathrm{o}}$ dan menerima $\mathrm{H}_{\mathrm{a}}$. Berdasarkan hal tersebut, maka peningkatan penguasaan konsep mahasiswa pada materi Penguatan Logam yang menggunakan multimedia animasi dapat dikatakan lebih baik daripada peningkatan penguasaan konsep mahasiswa yang menggunakan media diktat, hal ini berarti terdapat pengaruh penggunaan multimedia animasi terhadap peningkatan penguasaan konsep mahasiswa yang menggunakan multimedia animasi pada proses pembelajarannya jika dibandingkan dengan penguasaan konsep mahasiswa yang menggunakan yang menggunakan diktat.

Terdapat pengaruh penggunaan multimedia animasi terhadap peningkatan penguasaan konsep mahasiswa dengan menggunakan multimedia animasi maupun media diktat, pembelajaran menggunakan multimedia animasi dapat meningkatkan penguasaan konsep yang lebih baik dibandingkan pembelajaran menggunakan media diktat. Peningkatan penguasaan 
konsep mahasiswa yang menggunakan multimedia animasi dalam proses pembelajarannya berkaitan dengan ciri dan karakteristik dari multimedia animasi itu sendiri (Arsyad, 2010). menyatakan bahwa multimedia animasi termasuk kedalam media hasil penggabungan teknologi cetak dan komputer yang menggabungkan antara teks, gambar atau visual yang statis dan dinamis serta audio yang semua ini dikendalikan oleh komputer, sehingga dalam prosesnya melibatkan banyak interaktivitas. Multimedia animasi ini juga dinilai dapat merangsang untuk melakukan latihan, simulasi dan lain sebagainya. Animasi dapat menambahkan kesan realisme, dapat merangsang mengadakan latihan, kegiatan laboratorium, simulasi dan sebagainya (Sudjana dan Rivai, 1989). Hal tersebut dipengaruhi dari hasil manipulasi teoritis (gambar) menjadi realistis sehingga menarik perhatian pengguna animasi untuk belajar.

Mahasiswa yang menggunakan media diktat pada proses pembelajarannya memiliki hasil penguasaan konsep yang lebih rendah jika dibandingkan dengan hasil penguasaan konsep mahasiswa yang menggunakan animasi, untuk hal ini berkaitan dengan karakter yang dimiliki oleh diktat sebagai media belajar. Diktat merupakan media yang termasuk kedalam teknologi cetak yang memiliki salah satu ciri yaitu teks dan visual yang ditampilkan secara statis (diam) (Arsyad, 2010). Dikarenakan ciri media diktat tersebut yang statis, daya tarik yang dihasilkan kurang dapat membuat mahasiswa memberikan perhatiannya pada proses pembelajaran berlangsung. Dikaitkan dengan mata kuliah material teknik banyak menjelaskan mengenai hal yang tak kasat mata atau mikroskopis, jenis media diktat ini kurang dapat memfasilitasi keadaan tersebut yang menyebabkan mahasiswa kesulitan untuk menggambarkan materi yang disampaikan.

Dapat dikatakan bahwa penggunaan media diktat maupun multimedia animasi pada pembelajaran, dapat meningkatkan penguasaan konsep mahasiswa. Hal ini didukung oleh data penelitian dengan melihat peningkatan nilai hasil belajar mahasiswa setelah mendapatkan treatment dari kelompok kontrol maupun kelompok eksperimen. Media meningkatkan kemampuan keterbacaan baru. Perbedaan penggunaan media diktat dan multimedia animasi dalam pembelajaran terdapat pada besarnya hasil yang didapat atau dapat dikatakan bahwa perbedaannya terdapat pada peningkatan nilai hasil belajar yang merupakan peningkatan penguasaan konsep pada penelitian ini. 
Rendahnya peningkatan hasil belajar pada kelompok kontrol yang menggunakan media diktat tidak terlepas dari penyajian media tersebut. Penyajian media tersebut salah satunya adalah kurang dapat menjelaskan teori Penguatan Logam. Pada media animasi materi definisi Penguatan Logam salah satunya memberikan contoh dari pergerakan atom-atom dari struktur kristal, sedangkan media diktat hanya menyajikan visualisasi atom-atom berupa gambar diam, animasi dari pergerakan atom-atom tersebut akan lebih memperjelas dan mempermudah siswa untuk memahami materi pembelajaran dengan baik. Berdasarkan penjelasan penyajian media, maka dapat dikatakan bahwa pembelajaran pada materi Penguatan Logam yang di dalamnya terdapat pergerakan atom-atom ini dapat dipahami jika dibantu dengan animasi, sedangkan tanpa media animasi proses pembelajaran pada pergerakan atom-atom ini tidak dapat dilakukan dengan optimal. Aanimasi dapat membantu proses pelajaran jika peserta diklat hanya akan dapat melakukan proses kognitif jika dibantu animasi, sedangkan tanpa animasi proses kognitif tidak dapat dilakukan (Susilana dan Riyana, 2009).

Peningkatan penguasaan konsep pada kelompok eksperimen tidak lepas dari penjelasan multimedia animasi yang lebih konkret dibandingkan dengan media diktat. Kerucut pengalaman menunjukkan bahwa semakin konkret penjelasan sebuah media pembelajaran pada suatu proses pembelajaran, maka akan semakin banyak pengalaman yang didapat oleh peserta didik. Sehingga dapat dikatakan bahwa penggunaan media pembelajaran yang lebih konkret akan menghasilkan peningkatan penguasaan konsep yang lebih baik (Dahar, 2011).

Berdasarkan karakteristik materi Penguatan Logam pada Latar Belakang, materi Penguatan Logam merupakan materi dengan konsep yang abstrak, dinamis, dan kompleks. Konsep yang abstrak, dinamis, dan kompleks ini sulit dijelaskan jika dengan menggunakan gambar atau kata-kata saja, sehingga peningkatan penguasaan konsep dengan menggunakan multimedia animasi akan lebih baik daripada peningkatan penguasaan konsep dengan menggunakan media diktat. Uraian pembahasan diatas dapat memberikan gambaran bahwa terdapat pengaruh penggunaan Multimedia Animasi terhadap peningkatkan penguasaan konsep mahasiswa pada pembelajaran materi Penguatan Logam jika dibandingkan dengan media yang digunakan oleh dosen sebelumnya yang hanya berupa media diktat. 


\section{KESIMPULAN}

Kesimpulan ini diperoleh, sebagai berikut: peningkatan penguasaan konsep mahasiswa dalam pembelajaran materi Penguatan Logam pada mata kuliah Material Teknik dengan menggunakan diktat berada dalam kategori rendah dan dengan menggunakan multimedia animasi berada dalam kategori sedang. Pembelajaran menggunakan multimedia animasi berpengaruh terhadap peningkatan penguasaaan konsep mahasiswa pada materi Penguatan Logam mata kuliah Material Teknik.

\section{DAFTAR PUSTAKA}

Arsyad A. (2010). Media Pembelajaran. Jakarta: PT. Raja Grafindo Persada.

Dahar, R.W. (2011). Teori-teori Belajar dan Pembelajaran, Jakarta: Erlangga.

Sudjana, N. \& Rivai, A. (1989).Teknologi Pengajaran. Bandung: Sinar Baru.

Susilana, R. \& Riyana, C. (2009). Media Pembelajaran. Bandung: CV. Wacana Prima. 